\title{
The role of bedside ultrasonography for occult scaphoid fractures in the emergency department
}

\author{
Acil serviste gizli skafoid kırıkları için yatakbaşı ultrasonografinin rolü
}

\author{
Ahmet YILDIRIM, Erden Erol ÜNLÜER, Nergiz VANDENBERK, Arif KARAGÖZ
}

\section{BACKGROUND}

Our aim is to study the accuracy of emergency medicine (EM) physician-performed, bedside ultrasonography (BUS) in patients with clinical suspicion of scaphoid fracture and normal radiographs.

\section{METHODS}

From January to December 2011, an EM physician used BUS to prospectively evaluate patients presenting to the emergency department (ED) with clinical suspicion of scaphoid fracture and normal radiographs. BUS examination of the scaphoid was conducted prior to a wrist magnetic resonance imaging (MRI) scan, within 24 hours of wrist trauma. The outcome was determined by official radiology reports of the MRI. The results were compared using the chi-square test.

\section{RESULTS}

Of the 63 enrolled patients, 12 Patients were BUS-positive. Of these, MRI results agreed with the BUS findings in 12 patients who had cortical damage of the scaphoid with hematoma. In 35 instances, hematoma with no cortical damage was detected with BUS and corroborated by MRI. A scaphoid fracture was demonstrated by MRI in two patients from this group. The sensitivity, specificity, positive predictive value, negative predictive value, and negative likelihood ratio for BUS were $85.7 \%, 100 \%, 100 \%, 100 \%$ and 0.14 , respectively. Accuracy of BUS was not statistically different from MRI.

\section{CONCLUSION}

The diagnosis of scaphoid fractures is another BUS application in the ED. EM physicians should consider diagnosis of scaphoid fractures using BUS in the emergency department.

Key Words: Bedside ultrasonography; emergency; fracture; scaphoid.

\section{$A M A C ̧$}

Amacımız, skafoid kırığg1 yönünden klinik şüphe taşıyan fakat radyografileri normal olan hastalarda acil tıp hekimi tarafindan yapılan yatakbaşı ultrasonografinin (USG) doğruluğunu araştırmaktır.

\section{GEREÇ VE YÖNTEM}

2011 yılı Ocak-Aralık ayları arasında bir acil tıp hekimi, acile başvuran ve skafoid kırığı yönünden klinik şüphe taşıyan fakat radyografileri normal olan hastaları ileriye dönük olarak değerlendirmek için yatakbaşı USG'yi kullandı. Yatakbaşı USG, el bileği travmasını izleyen ilk 24 saat içinde ve el bileğinin manyetik rezonans (MR) görüntüleme incelemesinden önce uygulandı. Sonuç, MR görüntülemenin resmi radyolojik raporuyla belirlendi. Sonuçlar istatistiksel olarak ki-kare testi ile karşılaştırıldı.

\section{BULGULAR}

Çalışmaya alınan 63 hastanın 12'sinde yatakbaşı USG ile kırık saptandı. Bu 12 hastanın tamamında MR görüntülemede skafoid kemikte kortikal hasar ve hematom izlendi ve sonuç yatakbaşı USG'yi doğruladı. Otuz beş hastada ise yatakbaşı USG ile kortikal hasar olmadan hematom saptandı ve MR görüntüleme ile bu bulgu doğrulandı. Bu gruptaki 2 hastada MR görüntüleme ile skafoid kırığı saptandı. Yatakbaşı USG için duyarlılık, özgüllük, pozitif prediktif değer, negatif prediktif değer ve negatif olabilirlik oranı s1rasıyla $\% 85,7, \% 100, \% 100, \% 100$ ve 0,14 'tür. Yatakbaş1 USG'nin doğruluğu istatistiksel olarak MR görüntülemeden farklı değildir.

\section{SONUÇ}

Skafoid kırıklarının tanısı, acil serviste yatakbaşı USG'nin başka bir uygulama alanıdır. Acil tıp hekimleri, acil serviste skafoid kırıklarının tanısını yatakbaşı USG'yi kullanarak koyabilirler.

Anahtar Sözcükler: Yatakbaș1 ultrasonografi; acil; kırık; skafoid. Acil Tıp Kliniği, İzmir. 
Traumatic injury of the wrist is a common reason for patients to visit an emergency department (ED). Wrist trauma is a frequent cause of consultation in the emergency room that effects all ages but predominantly young patients. The scaphoid is one of the most frequently fractured carpal bones. ${ }^{[1]}$ The evaluation of the wirst and hand injury generally consists of patient history and physical examination that is frequently complemented with diagnostic imaging. The clinical criteria for diagnosis of a suspected scaphoid fracture are wrist pain associated with tenderness on axial loading of the first ray of the elbow bones and swelling with tenderness at palpation of the anatomic snuffbox. Moreover, some fractured scaphoids may be occult at presentation and cannot be seen on the initial direct Xrays ordered after trauma. The routine radiographic series ordered for a suspected scaphoid fracture includes a neutral posteroanterior view and a lateral projection of the wrist, together with additional views such as a semipronated oblique scaphoid view, and a posteroanterior view with ulnar deviation. Nevertheless, 20$25 \%$ of patients with fractured scaphoid have positive findings in physical examination but normal radiology reports following direct X-ray. ${ }^{[2]}$

Magnetic resonance imaging (MRI) is a more appropriate diagnostic modality for demonstration of a scaphoid fracture, but the high costs and limited availability, as well as the long duration of the examination, have been a major hindrance to a wide application of MR imaging for wrist and hand injury. The technological development of ultrasound equipment and the availability of high frequency electronic transducers allows for an accurate evaluation of scaphoid fracture.

In this study, we aimed to determine the accuracy of EM physician-performed bedside ultrasonography (BUS) in patients with history of hand trauma and suspected scaphoid fractures.

\section{MATERIALS AND METHODS}

The Ethics Committee of a local tertiary care government teaching hospital approved our study protocol.

Sixty-three consecutive adult patients older than 18 years, admitted to our emergency department with clinical suspicion of scaphoid fracture and normal radiographs, underwent BUS examination of the scaphoid prior to a wrist MRI scan within 24 hours of wrist trauma. BUS examinations were performed by EM physicians who had undergone six hours of didactic and three hours of hands-on training with a radiologist in hand and wrist ultrasound techniques and the diagnosis of scaphoid fractures. The EM physicians examined patients for the presence of a cortical interruption of the scaphoid along with a radiocarpal or scaphotrapezium trapezoid effusion.

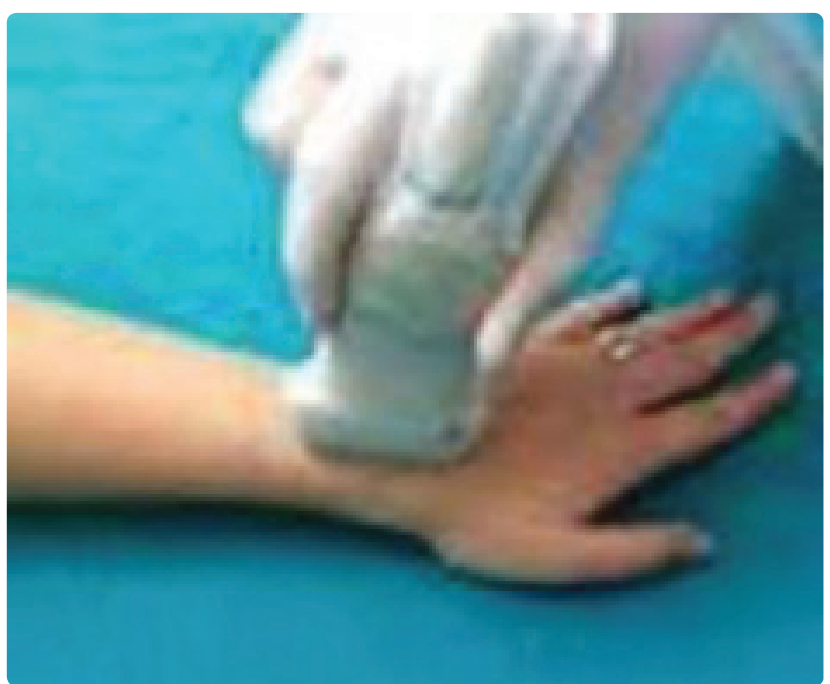

Fig. 1. Orientation of ultrasonography probe while longutudinal scanning of the scaphoid bone.

(Color figur can be viewed in the online issue, which is available at www.tjtes.org).

Between January and December 2011, during shifts when one of the trained EM physicians was working in the ED, patients over 18 years old with clinical suspicion of a scaphoid fracture and radiographs underwent BUS examination of the scaphoid prior to a wrist MRI within 24 hours of wrist trauma. The clinical criteria for a suspected scaphoid fracture were wrist pain associated with tenderness on axial loading of the first ray and swelling and tenderness at palpation of the anatomic snuffbox. The routine radiographic series for a suspected scaphoid fracture consisted of a neutral posteroanterior and a lateral projection of the wrist together with additional views of the scaphoid, a semi-pronated oblique scaphoid, and a posteroanterior

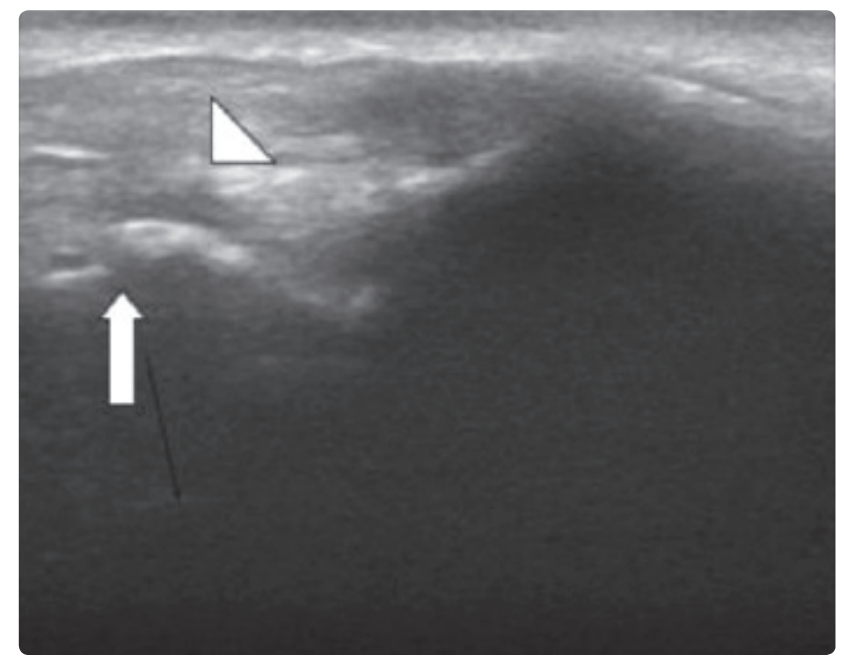

Fig. 2. Longitudinal view of the scaphoid bone with ultrasound shows cortical discontinuity (white arrows), along with radio-carpal effusion and surrounding hematoma, suggestive of scaphoid fracture (white arrow head). 
Table 1. Comparision of MR image and BUS findings in the diagnosis of scaphoid fracture

\begin{tabular}{|c|c|c|c|c|c|c|}
\hline \multirow[b]{3}{*}{ BUS } & \multicolumn{4}{|c|}{ MR image } & & \\
\hline & \multicolumn{2}{|c|}{ Fracture positive } & \multicolumn{2}{|c|}{ Fracture negative } & \multicolumn{2}{|c|}{ Total } \\
\hline & $\mathrm{n}$ & $\%$ & $\mathrm{n}$ & $\%$ & $\mathrm{n}$ & $\%$ \\
\hline Fracture positive & 10 & 100.0 & 23 & 65.7 & 33 & 73.3 \\
\hline Fracture negative & 0 & 0.0 & 12 & 34.3 & 12 & 26.7 \\
\hline Total & 10 & 22.2 & 35 & 77.8 & 45 & 100.0 \\
\hline
\end{tabular}

view with the wrist in ulnar deviation. Patients with positive radiographs for scaphoid or other wrist bone fractures were excluded from the study.

Immediately following the clinical examination, US was performed by the emergency physician. Images were obtained using the standard equipment available in the emergency department (DC 3, Mindray Bio-medical Electronics Co., Shenzhen, China), with a small, compact linear (5-13 MHz) transducer for superficial structures. The examination was made through transmission sonographic gel. Using the anatomical landmarks of the wrist, and commencing the examination at the radius, the scaphoid was identified by its bi-lobed or peanut shape with a smooth and hyperechoic bone surface contour. ${ }^{[3]}$ In order to correctly elongate the scaphoid, the hand was positioned in ulnar deviation, both in frontal and sagittal planes. A neutral frontal plane image, with the palm lying on the table, was also obtained to assess the dorsal aspect of the bone (Fig. 1). Using these different wrist positions, BUS examination covered the volar, dorsal, and lateral aspects of the scaphoid, with images obtained in the longitudinal and axial planes of the bone. The radiocarpal and midcarpal recesses were inspected in the sagittal plane, for both the dorsal and volar planes of examination. ${ }^{[3,4]}$

The emergency medicine physician was asked to assess the continuity of the scaphoid cortex (seen as a smooth, thin, hyperechoic line) and the presence of fluid effusion in the radioscaphoid and scaphotrapezium trapezoid spaces (Fig. 2). ${ }^{[3,5]}$ Signs associated with scaphoid fracture were either the cortical disruption of the scaphoid contour, producing a focal deformity, or hemarthrosis, seen as hypoechoic fluid in the radioscaphoid or scaphotrapezium trapezoid spaces. ${ }^{[6,7]}$ These findings have been reported in the literature as the most suggestive signs associated with scaphoid fracture. ${ }^{[3,5,8]}$ MRI of the wrist was performed within 24 hours of the sonographic examination.

The patient was placed prone on the examination table, with the hand positioned in full pronation. Images were routinely reformatted with a $2 \mathrm{~mm}$ thickness in coronal and sagittal planes. Immediately after BUS scanning, an MRI was performed by a radiologist. The radiologist's official report of the MR images was accepted as definitive in this study.

\section{Data analysis}

Sensitivities, specificities, positive predictive values (PPVs), and negative predictive values (NPVs) of BUS were calculated and analyzed using SPSS, version 15.0 (SPSS, Inc, Chicago, USA). The chi-square test and the kappa statistic were used to compare EM physicians.

\section{RESULTS}

During the study period, 63 patients with suspected wrist injuries were evaluated by the study physicians in our ED. All 63 patients $(52.4 \%$ female, mean age $39.6 \pm 18.3$ years, range $18-79$ years of age) agreed to participate in the study.

A scaphoid fracture was eventually demonstrated by MRI scan in 14 patients. BUS examination revealed signs suggestive of scaphoid fracture in 12 of the 14 patients with an MRI proven fracture. Of these, 12 were corroborated by MR images (true positive), and 0 found to be negative (false negative) (Table 1).

In 45 cases, BUS was negative for scaphoid fracture, of which two were revealed to have a scaphoid fracture following the MRI (false negatives; Table 2). The results of BUS diagnoses of scaphoid fractures are listed in Table 2. The diagnostic accuracy of BUS

Table 2. Results for bedside ultrasonography for diagnosis of scaphoid fracture

\begin{tabular}{lcc}
\hline & $\begin{array}{c}\text { Bedside } \\
\text { ultrasonography }\end{array}$ & $95 \%$ CI \\
\hline Sensitivity & 100.0 & $69.2-100.0$ \\
Specificity & 34.29 & $19.1-52.2$ \\
Positive predictive value & 30.3 & $15.6-48.7$ \\
Negative predictive value & 100.0 & $73.5-88.8$ \\
+ Likelihood radio & 1.52 & $1.0-2.4$ \\
- Likelihood radio & 0.00 & - \\
Area under curve & 0.671 & $0.515-0.804$ \\
\hline
\end{tabular}


and MRI did not differ significantly (kappa $=0.188$, $\mathrm{p}=0.031$ ). A receiver operating characteristic (ROC) curve analysis was conducted to illustrate the performance of BUS in the diagnosis of scaphoid fractures (Table 2).

\section{DISCUSSION}

EM physicians have used BUS to evaluate trauma patients since the early $1980 \mathrm{~s} .{ }^{[9-12]}$ There is a growing body of evidence that patient care improves when ultrasound is included in the diagnostic workup of multiple-trauma patients. ${ }^{[13,14]}$ Deployment of ultrasound in emergency departments could potentially provide critical information concerning traumatized patients and thereby optimize patient care. Ultrasonography has been widely used by emergency physicians to accurately diagnose many disease processes at the bedside with high sensitivity and specificity. ${ }^{[15-18]}$

Improvements in ultrasound technology, and increasing clinical experience with ultrasonography, has led to its common use in situations such as thoracoabdominal trauma, ectopic pregnancy, abdominal aortic aneurysm, pericardial effusion, cardiac arrest, biliary disease, renal tract disease, and small bowel obstruction, and in procedures such as lumbar puncture, arthrocentesis and central venous access. ${ }^{[18-20]}$ As a result, the emergency physician is ideally suited for the use of ultrasound technology at the patient's bedside since these physicians are frequently presented with acutely ill or injured patients requiring immediate treatment.

Traumatic injury of an extremity is one of the most common reasons for patients to visit an ED. The technological development of ultrasound equipment, and the availability of high frequency electronic transducers, allows an accurate evaluation of scaphoid fractures.

Our study is one of the first to demonstrate the ability of EM physicians to evaluate scaphoid fractures using BUS. The results of our study suggest that the accuracy of BUS assessment performed by EM physicians trained in wrist and hand ultrasonography is comparable to that of radiologists performing US, and the two methods correlated well in this study. To our knowledge, this is the first study to assess the accuracy of BUS when performed by EM physicians trained in the performance and interpretation of this technique in relation to wrist joints.

One limitation of our study was that the EM physicians were aware of the patients' clinical assessments. Since the EM physicians knew they were being evaluated, they may have been more motivated to enhance their performance according to the criteria being studied. Since no standards exist for training EM physicians in the use of BUS for wrist joint evaluation, we cannot assume that our training program was adequate. Further research needs to be performed to validate our suggested BUS methodology for detecting scaphoid fractures.

In conclusion, the use of BUS in the ED to evaluate damage to wrist joints has the potential to improve the time required to diagnose fractures and to provide prompt care for patients with wrist and hand trauma. Our study shows that EM physicians can perform BUS to detect scaphoid fractures in the ED with a high degree of accuracy.

Conflict-of-interest issues regarding the authorship or article: None declared.

\section{REFERENCES}

1. Haisman JM, Rohde RS, Weiland AJ; American Academy of Orthopaedic Surgeons. Acute fractures of the scaphoid. J Bone Joint Surg [Am] 2006;88:2750-8.

2. Hauger O, Bonnefoy O, Moinard M, Bersani D, Diard F. Occult fractures of the waist of the scaphoid: early diagnosis by high-spatial-resolution sonography. AJR Am J Roentgenol 2002;178:1239-45.

3. Jacobson JA. Fundamentalis of musculosketeal ultrasonud. Philadelphia: Saunders Elsevier; 2007.

4. Herneth AM, Siegmeth A, Bader TR, Ba-Ssalamah A, Lechner G, Metz VM, et al. Scaphoid fractures: evaluation with high-spatial-resolution US initial results. Radiology 2001;220:231-5.

5. Schubert HE. Scaphoid fracture. Review of diagnostic tests and treatment. Can Fam Physician 2000;46:1825-32.

6. Jelbert A, Vaidya S, Fotiadis N. Imaging and staging of haemophilic arthropathy. Clin Radiol 2009;64:1119-28.

7. Zukotynski K, Jarrin J, Babyn PS, Carcao M, PazminoCanizares J, Stain AM, et al. Sonography for assessment of haemophilic arthropathy in children: a systematic protocol. Haemophilia 2007;13:293-304.

8. Fusetti C, Poletti PA, Pradel PH, Garavaglia G, Platon A, Della Santa DR, et al. Diagnosis of occult scaphoid fracture with high-spatial-resolution sonography: a prospective blind study. J Trauma 2005;59:677-81.

9. Viscomi GN, Gonzalez R, Taylor KJ, Crade M. Ultrasonic evaluation of hepatic and splenic trauma. Arch Surg 1980;115:320-1.

10. Weill F, Bihr E, Rohmer P, Zeltner F, Le Mouel A, Perriguey G. Ultrasonic study of hepatic and splenic traumatic lesions. Eur J Radiol 1981;1:245-9.

11. Tso P, Rodriguez A, Cooper C, Militello P, Mirvis S, Badellino MM, et al. Sonography in blunt abdominal trauma: a preliminary progress report. J Trauma 1992;33:39-43.

12. Rozycki GS, Ochsner MG, Jaffin JH, Champion HR. Prospective evaluation of surgeons' use of ultrasound in the evaluation of trauma patients. J Trauma 1993;34:516-27.

13. Melniker LA, Leibner E, McKenney MG, Lopez P, Briggs WM, Mancuso CA. Randomized controlled clinical trial of point-of-care, limited ultrasonography for trauma in the emergency department: the first sonography outcomes assessment program trial. Ann Emerg Med 2006;48:227-35.

14. Ollerton JE, Sugrue M, Balogh Z, D’Amours SK, Giles A, Wyllie P. Prospective study to evaluate the influence of FAST on trauma patient management. J Trauma 2006;60:785-91.

15. Rowland JL, Kuhn M, Bonnin RL, Davey MJ, Langlois SL. Accuracy of emergency department bedside ultrasonogra- 
phy. Emerg Med (Fremantle) 2001;13:305-13.

16. Brooks A, Davies B, Smethhurst M, Connolly J. Prospective evaluation of non-radiologist performed emergency abdominal ultrasound for haemoperitoneum. Emerg Med J 2004;21:e5.

17. Soyuncu S, Cete Y, Bozan H, Kartal M, Akyol AJ. Accuracy of physical and ultrasonographic examinations by emergency physicians for the early diagnosis of intraabdominal haemorrhage in blunt abdominal trauma. Injury 2007;38:564-9.

18. Davis DP, Campbell CJ, Poste JC, Ma G. The association be- tween operator confidence and accuracy of ultrasonography performed by novice emergency physicians. J Emerg Med 2005;29:259-64.

19. American College of Emergency Physicians. American College of Emergency Physicians. Use of ultrasound imaging by emergency physicians. Ann Emerg Med 2001;38:469-70.

20. Unlüer EE, Yavaşi O, Eroğlu O, Yilmaz C, Akarca FK. Ultrasonography by emergency medicine and radiology residents for the diagnosis of small bowel obstruction. Eur J Emerg Med 2010;17:260-4. 